\title{
Erratum to: Rapid and Sensitive Detection of Staphylococcus aureus in Food Using Selective Enrichment and Real-Time PCR Targeting a New Gene Marker
}

Tereza Trnčíková • Vendula Hrušková • Katarína Oravcová • Domenico Pangallo • Eva Kaclíková

Published online: 27 March 2013

(C) Springer Science+Business Media New York 2013

Erratum to: Food Anal. Methods (2009) 2(4):241-250

\section{DOI 10.1007/s12161-008-9056-x}

There is a mistake in the probe sequence in the text of Material and Methods. It should have been 5 '-cttgetccgtttcac caggcttcggtg-3' instead of 5'-cttgctccgttcaccaggcttcggtgt-3' (without the last " $\mathrm{t}$ ").

The online version of the original article can be found at http://dx.doi.org/ 10.1007/s12161-008-9056-x.

T. Trnčíková $\cdot$ V. Hrušková $\cdot$ K. Oravcová $\cdot$ E. Kaclíková $(\bowtie)$

Department of Microbiology and Molecular Biology,

Food Research Institute,

P.O. Box 25, 82475 Bratislava, Slovakia

e-mail: kaclikova@vup.sk

V. Hrušková

Institute of Food Science and Biotechnology,

Faculty of Chemistry, Brno University of Technology,

Brno, Czech Republic

D. Pangallo

Institute of Molecular Biology, Slovak Academy of Science,

Bratislava, Slovakia 